\title{
THE INFLATED VALUATION PROBLEM IN VALENCIA, SPAIN, AND IMPLICATIONS FOR FIRM SIZE
}

\author{
Natividad GUADALAJARA*, Miguel A. LÓPEZ \\ Department of Economy and Social Sciences, Universitat Politècnica de València, Camino de Vera, \\ s/n 46022 Valencia, Spain
}

Received 20 December 2017; accepted 27 April 2018

\begin{abstract}
Home purchase-sale prices have been widely modeled by several authors. Nonetheless, other values exist, such as home mortgage appraisal values, used by financial institutions, which have played a key role in the recent financial crisis. This article attempts to model the appraisal price of one $\mathrm{m}^{2}$ of residential properties obtained by 31 appraisal companies in Valencia (Spain). Mortgage appraisal values of 17007 residential properties were used for this purpose. Spatial autocorrelation was detected in both the data and residuals of the ordinary regression model, which justified using spatial regression models. Of the four employed models, the error model offered the best results. Significant differences were found among appraisal companies, which varied as much as $83 \%$ for some. Generally speaking, small appraisal companies obtained higher over-valuation percentages, which confirms their situation of weakness. The fact that over-valuations exist in mortgage securities is a high risk for a stable financial system.
\end{abstract}

Keywords: firm size, housing, mortgage, overvaluation, spatial.

\section{Introduction}

Valuations for residential properties imply obtaining the market value, and this information is neither observable nor hypothetical. Therefore, appraisal companies quite often pay attention to formerly valued prices, which often results in biased valuations (Tidwell \& Gallimore, 2014). Specifically, behavioural research erupted in real-estate valuation research in the early 1990s. Klamer, Bakker, and Gruis (2017) provide a systematic review of empiri$\mathrm{cal}$ research on real-estate valuer judgements in the last 30 years and analyzed 32 relevant papers. They define the appraiser's bias as the deviation from valuation procedures established to process information. They indicate two bias types: intrapersonal and interpersonal. Interpersonal biases affect the relationship between the valuer and his/her client, and address the effects of client influence on valuer decision-making processes. Almost all the studies on interpersonal bias are conducted by survey research, which has been preformed between 1996 and 2005 in the USA and Nigeria using sample particpants.

The potential factors that affect the client influence (Levy \& Schuck, 1999) fall into four main categories: the characteristics of the individual or organization providing the service; the characteristics of the client (in particular, mortgage bankers as the primary sources of client pressure, followed by commercial banks); external characteristics, including the regulatory framework, professional criteria and current markets conditions; the characteristics of the service to be provided.

Baffour Awuah and Gyamfi-Yeboah (2017) examine the extent of variations in valuations and the effect of complex valuation tasks on the levels of variations in Ghana. Their study finds high levels of variations in the valuation opinions of $33.6-63 \%$ for archival data and survey data, respectively.

There could be four types of influence on the valuer (Levy \& Schuck, 2005): expert power; information power; reward and coercitive power; procedural power. Expert power is particularly manifiested in those clients that are large corporations and is materialized in knowledge about valuation processes and the client's participation in the market.

Amidu and Aluko (2007) quantitatively compared the factors set out by Levy and Schuck (1999) about valuers in Nigeria. The results they obtained by holding interviews quantitatively confirmed that pointed out by Levy and Schuck in general lines. The most important influence factors were the integrity of either the valuer or of the

${ }^{*}$ Corresponding author. E-mail: nguadala@omp.upv.es 
valuation company, the importance of the valuation result for the client, and the client's size. However, the statistical tests found no relationship linking the society's size, experience, level of training and perceiving clients' relative importance.

Along these lines, Gallimore and Wolverton (2000) analyzed the influence that a client's opinion has on mortgage valuations in the UK (which they previously did in the USA) to determine whether the objectiveness of the valuation from the established procedures used to calculate the value predominates, or if the valuer certifies the agreed buying/selling price. Unlike the results obtained in the USA, in the UK no adaptation to the customer's interests was noticed in the valuations of mortgage securities.

This in turn favors an increase in turnover and in the number of assignments with suppliers-appraisers that accept the guidelines (normally increases in the value, or at least easing valuations), although it could even imply reduced values, depending on the circumstances; this occurs with fund managers to be able to subsequently increase values gradually and to ensure that portfolios maintain a constant profitability (Levy \& Schuck, 1999).

Crosby, Lizieri, and McAllister (2010) analyzed appraisers' different behaviors depending on whether property funds on which they made valuations were open or closed. For the former, these authors observed a clearly incentive to make "downward" valuations because, in many cases, the funds only had access to liquidity by selling assets. Thus in any case, market values had to be compared with sales periodically, and managers did not desire any very brusque movements, which was the opposite to what occurred with close funds for which there was no need to make sales in the same way.

Hordijk and Van de Ridder (2005) analyzed the methodology that uses appraisers in the Netherlands to check if they fulfill valuation regulations, and if consistency and uniformity actually exist between valuation models, and what their variation is.

Valuation methods quite often neglect the inclusion of the real-estate market's natural cyclic behavior, especially in non transparent markets with very few transactions. This could be one of the factors behind the property bubble and the subsequent crisis that financial markets recently experienced. Hence it is important that the valuation methodology underlines sustainability over time, especially with the valuations required to grant loans with a mortgage guarantee. What is more, the recent property boom (Agnello \& Schuknecht, 2011) has been the longest in the last four decades, and suggests that the credits offered to families could have significantly influenced the rises and falls in housing prices during the 1980-2007 period. Cerruti, Dagher, and Dell'Ariccia (2017) also observed a close dynamic relation between home credit and a rise in housing prices.

Some works have centered on comparing valuations of residential properties with home purchase-sale prices. Chinloy, Cho, and Megbolugbe (1997) observed some systematically higher valuations than purchasing data throughout the 1975-1993 period. Conversely, Cho and Megbolugbe (1996) found that valuations were lower in $80 \%$ of cases, while appraisal and transaction prices were identical in $30 \%$ of cases.

When appraisal values are above the hedonic estimations of housing values, they increase the risk of a mortgage not being paid. So, it is important to develop quality appraisal measures that impact the corresponding mortgage loan (Lacour-Little \& Malpezzi, 2003).

Bowcock (2015) pointed out that mortgage valuations impacted the level of housing prices during the property bubble period from 2000 to 2008, which considerably contributed to the recession that followed, which was much less inferior than in those which occurred in 1972 and 1990. Despite the International Monetary fund's warning in 2004 about prices being too high and home purchasers having to be very careful, no basic research into the contribution made by those responsible for mortgage valuations appears to have been conducted. Agnello and Schuknecht (2011) stated that the deregulation of financial markets considerably reinforced the impact that the national financial sector had on booms appearing.

Moreover, mass valuation hedonic models are frequently used in mortgage valuations to offer a rapid service and to cut costs. In such models, geographic information systems (GIS) technology can be very useful in financing mortgages and in related industries (Belsky, Can, \& Megbolugbe, 1998). Indeed the higher potential contribution of GIS may be managing credit risks, property and agencies, marketing, complying with regulations and R\&D. Initially, the vast majority of existing applications were based, to a great extent, on managing spatial databases and map support functions, and barely any emphasis was placed on their analytical spatial capacities. Nonetheless, the applications of prototypes and R\&D applications were recently based on spatial statistics and spatial econometric modeling.

Due to the recent peak in and burst of US landed estate, the refinement and a more in-depth understanding of the methods used to value landed estate have become dire concerns of a series of broad academic fields related with the city. One of the main trends in the real-estate valuation field is expanding spatial econometrics (Krause \& Bitter, 2012).

The existence of spatial dependence in the real-estate sector, i.e., values of properties are interdependent as regards the nearest properties, is a frequently found circumstance in the real-estate market domain. This means that it is necessary to analyse whether this dependence arises in the analyzed spatial setting; if this spatial dependence exists, then it is absolutely necessary to measure the effect of this dependence on the explained variable.

Spatial hedonic models based on spatial econometrics date back to the studies presented in the 1980s and 1990s. Dubin (1998) developed a spatial hedonic regression model by including spatially autocorrelated error terms. Anselin (1988) indicated that there are two main causes for spatial autocorrelation. On the other hand, through errors 
of different kinds: imperfect data, mismatches between the area and the phenomenon that is being explained. Belsky et al. (1998) reviewed GIS and possibilities of using them in mortgage financing and risk management, commercialization, complying with the regulation, and in R\&D. Can $(1990,1992)$ also developed spatial aspects by including two questions: the contiguity effect and the neighborhood effect. She observed that the conventional autoregressive model was superior to classic hedonic models as they reflect the spatial effects of proximity with other factors that are located close to the property.

Many works have applied a spatial analysis to the realestate market (Affuso, Cummings, \& Le, 2017; Borst \& McCluskey, 2007; Brasington, 2004; Chegut, Eichholtz, \& Rodrigues, 2015; Zhang, Du, Geng, Liu, \& Huang, 2015).

The most direct procedure to determine the level of over-valuing appraisal values consists in comparing these values with the price of each property (Chinloy et al., 1997; Lacour-Little \& Malpezzi, 2003). Yet more often than not, this is not possible because in many countries like Spain, information about the transaction price of each property is not public information. Therefore, an alternative would be to estimate the level of prices using hedonic models and spatial models, which would include appraisal companies as factors that could influence the property's mortgage value. In this way, it is possible to quantify the influence it has on the estimated price, and on the company that did the appraisal, and to determine how much this value increases depending on which company valued, and to also homogeneously compare the differences among several companies.

For all these reasons, the present works aims to model the mortgage appraisal values of residential properties in Spain to analyze the influence that appraisal companies can have on these values, and to determine if there are any significant differences among them. This work is arranged in the following sections: Section 1 explains the situation in Spain and its mortgage appraisal company model. Section 2 describes the methodology and information sources used. Section 3 and Section 4 provides the results and the discussion, respectively. Finally, the last section presents the conclusions.

\section{The situation in Spain}

Spain has gone through a major economic crisis during the 2008-2014 period, and the real-estate sector has played a crucial role in its origin. In the 15 years running up to the crisis (1996-2008) (Aspachs-Bracons \& Rabanal, 2010), Spain witnessed a huge increase in residential property prices, and the importance of the construction sector for the Spanish economy as it grew to reach $10 \%$ of the GDP. This has sparked debate about drivers of property cycles.

Ever since Spain joined the European Monetary Union, two major factors could lie behind the peak in residential properties: lower nominal interest rates due to premiums for risk of currencies disappearing, demographic factors related to immigration and changes in compositions of homes.
Jimeno and Santos (2014) deal with three main characteristics of the Spanish economy during the period before the crisis began:

1) An economic activity that became increasingly more biased toward construction, the real-estate sector and other non marketable sectors.

2) A bank system capable of covering the huge increase in credit demanded by homes and companies at a time when interests were really low, with excessive optimism about growth, plus genuine facilities in employing real assets to back loans.

3) The external financing resources that led to an unparalleled increase in liabilities compared to the rest of the world.

In the center of this real-estate/financing hurricane, appraisal companies are found as those, which officially certify, in mortgage terms, values that have brusquely moved. They have been messengers that swiftly notified good news, and the necessary scapegoat to clean up any committed excesses.

For the appraisal values of properties to be considered valid in regulation terms, in Spain appraisals have to be made by appraisal companies that have been officially recognized by the Bank of Spain (Royal Decree 775/1997) by following a legally established methodology and report model (Ministerial Order ECO/805/2003).

Hence these appraisal companies' independence has been questioned by public opinion in recent years. Some studies conducted in Spain (García Montalvo, 2009; Akin, Montalvo, Garcia Villar, Peydro, \& Raya, 2014) state that appraisals values increased by around $29 \%$. These rising rates were motivated by the loan-value ratio not exceeding maximum levels, generally $80 \%$ of the value of securities, to comply with regulation-based bank demands.

It is worth considering if these practices still exist in Spain in the post-crisis era and, as a novel aspect, if all stakeholders respond similarly to possible incentives and pressures so that the valued value exceeds the market price.

What all this has led to is that since $2013,{ }^{1}$ a series of successive legal reforms have taken place to guarantee appraisal companies' independence in order to promote quality and transparent valuations, which do not escape being classified as being somewhat populist. The possibility of a bank being the owner of an appraisal company has practically been eliminated (it is interesting to note that the figure of the credit company's (the bank) internal appraisal service still remains theoretically, but not in practice), independence-reinforced mechanisms have been set up when faced with banks or other real-estate operators, and it is compulsory (in certain cases) to apply genuine Anglo-Saxon style codes of conduct.

Real-estate valuations form a fundamental part of valuing financial risks (it is not in vain that over $60 \%$ of bank assets are collateralized with properties) thus, as

\footnotetext{
1 See Art. 4 of Law 1/2013, of 14 May, on the measures to reinforce the protection of mortgage debtors, debt rearrangement and social rents.
} 


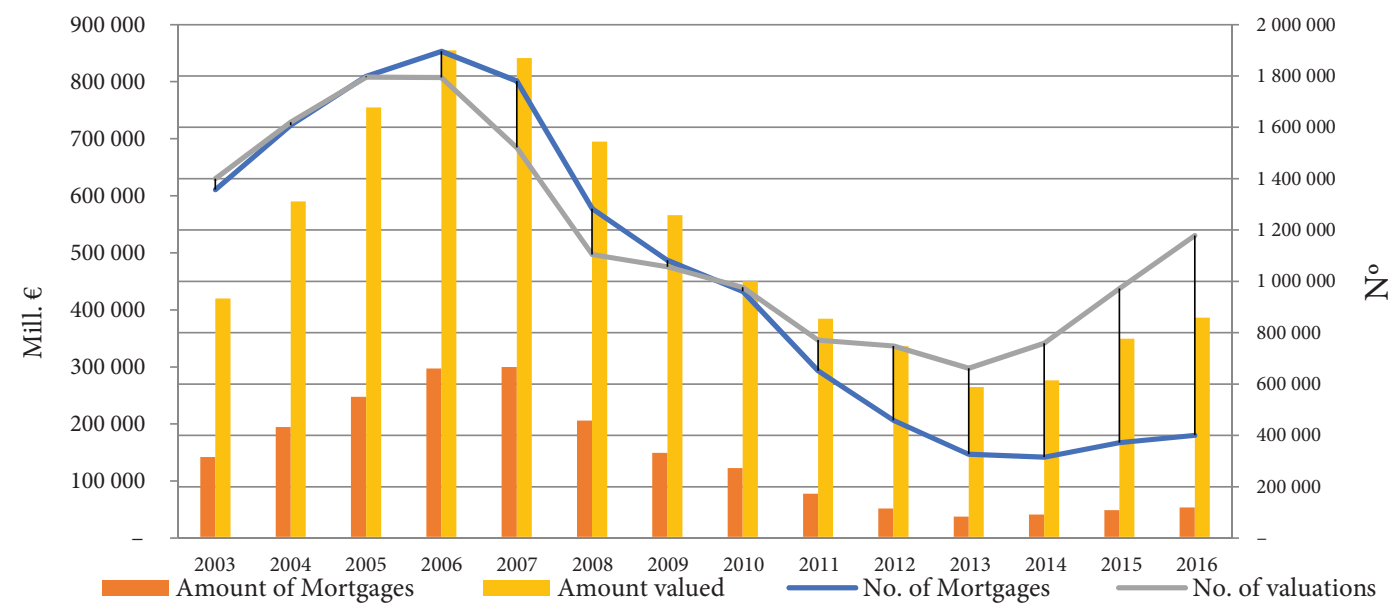

Figure 1. Evolution of mortgage activity and valuations in Spain

mitigators of the risk, their value affects capital requests, and the amount of losses foreseen for credit risks.

The bases of our valuation model, which was outlined during years of democracy, comprise four basic parts:

a) A specific valuation methodology exists, set out by Ministerial Order ECO/805/2003. This order regulates the report model and the methodology to be applied for certain purposes: mortgage security of the credits or loans that form, or will form, part of the portfolio cover of mortgage bonds; determining the reasonable value of assets into which the technical reserves of insurance and reinsurance companies materialize; determining the wealth of collective real-estate investment institutions; determining the real-estate wealth of Pension Trusts.

b) A societal valuation model exists. The professional valuer figure is a key figure in this activity being exercised, but a society contributes the technical means, homogenization and quality control for any work done individually.

Figure 1 shows the evolution of the last real-estate cycle. In 2006 the figure of 1.8 million valuations was reached ( $4 \%$ of the population), and the level of mortgages was similar. These figures drastically dropped to slightly over 300,000 mortgages ( $0.6 \%$ of the population) and to 661,000 valuations in 2013 . When the bubble peaked, almost $80 \%$ of the valuations made corresponded to a residential property, but they fell below $60 \%$ in 2014. More valuations than mortgages were seen from 2010, due fundamentally to the valuations of the stock of residential properties appropriated by the bank to pay off debts.

In the current cycle phase with less activity, it is easier to establish suitable control mechanisms so that the typical imbalances of peak phases do not take place because such a situation might end up transferring problems to the financial system with the devastating effects that we all know only too well.

c) An extensive in-depth report model exists.

d) The 36 appraisal companies officially recognized in 2017 are registered and supervised by the Bank of Spain. Their administrative system, which intends to promote quality transparent valuations, is set out in Royal Decree, 775/1997, of 30 May 1997.

Nonetheless, this model has the following weak points:

a) The shares-based dependence of credit companies or other stakeholders in the sector: although the number of shares-dependent companies has considerably lowered in recent years, it was necessary to set up a strict independence regime between the company that valued loan securities and the credit company that loaned them. The 2013 reform $^{2}$ does not allow a bank or banking group to hold more than $10 \%$ of a given appraisal company's capital.

b) Commercial dependence as regards credit companies: commercial dependence has been stressed by the number of credit companies lowering. Consequently, the 2013 reform established a set of reinforced independence requirements ${ }^{3}$, which basically consist in establishing a code of conduct that affects shareholders and groups of interest; e.g., credit companies.

c) A high concentration in the sector, with a large number of small-sized appraisal companies which find it increasingly difficult to find mortgage business opportunities. This would place them in a weak position as this situation could affect technical aspects and independence.

\footnotetext{
2 Law 1/2013, of 14 May; Ref. BOE-A-2013-5073.

3 This law establishes that "appraisal companies whose total income derives ... at least 10 percent of their business relation with a credit company, or with the series of credit companies of the same group, should, provided that some of these credit companies have issued, and have in circulation, mortgage bonds, have the suitable mechanisms to favor the independence of appraisal activity, and to avoid conflicts of interest, particularly with managers or units of credit companies which, without having any specific competences in risk analyses or management, are related with the awarding or commercialization of mortgage credits or loans. These mechanisms shall consist in at least one internal conduct regulation that establishes the incompatibilities of their managers and administrators... The obligation of having these mechanisms will also affect ... those appraisal companies in which shareholders have a significant influence, and who have specific interests either in promoting or commercializing properties, or activities which, as the Bank of Spain sees it, are similar in nature".
} 
d) A credit company adversely selecting an appraisal company.

e) A non transparent real-estate market. Public information about transaction prices, stocks of residential properties, buildings that have begun to be built, number of purchase-sales, and other data on such activity is quite scarce, inaccurate, but is gradually improving.

\section{Materials and methods}

\subsection{Materials}

We obtained 26140 valuations of multifamily residential properties in the Province of Valencia (east Spain), made in 2015 by 31 Spanish appraisal companies according to the requirements set out for the information contained in Ministerial Order ECO/805/2003, about rules of valuing properties and certain rights for some financial purposes. This information cannot be accessed by the general public and has been provided by the 31 appraisal companies to specifically conduct this study ${ }^{4}$.

Valencia has selected for its characteristics: the capital is one of the most popular cities in Spain. The coast is a very tourist area. Inside the province we can find mediumsized cities and small villages. The Province of Valencia is on the east coast of Spain and covers $10763 \mathrm{~km}^{2}, 644 \mathrm{~km}$ of which are coastline. It has a population of 2578.719 inhabitants (INE 2011; INE = Spanish National Statistics Institute) and 266 municipalities. It borders the Mediterranean Sea to the east.

In $2007,70 \%$ of the inhabitants in the province (1738.690) lived in the metropolitan area of its capital, the city of Valencia. The 2011 census of residential properties indicated 1452.545 such properties, which represents an average of 1.8 inhabitants per residential property.

Of the initial 26140 valuations, 9031 were eliminated because they corresponded to dwellings in one same building and were valued by the same company. Their values were replaced with their average value. Nor did we consider the values of those properties valued at more than $1 \mathrm{M} €$ (38 properties), or those whose value went below $€ 10000$ (64 properties) as they were considered atypical values. As a result, the database employed for the analysis contained 17007 records.

For each property, information about the name of the company that made the appraisal was available (namely S01 to S31). Since 10 such companies had made fewer than 75 appraisals, they were included as one group. Consequently, 21 appraisal companies were analyzed plus the one group (SRES) formed by the 10 companies, which resulted in 22 appraisal companies variables. This enabled us to see whether those companies that made a few valuations showed differential values to the rest.

\footnotetext{
4 For confidentiality reasons we cannot identify the appraisal companies. All the processed data are anonymous, and personal information (e.g. names of owners, location of houses, etc.) is never mentioned in the data set.
}

The appraisal company provided the appraisal value of the dwelling and its intrinsic characteristics. Socioeconomic information was also collected from INE, using census data of people and dwellings as $1 \mathrm{~km}^{2}$ grids. The $1 \mathrm{~km}^{2}$ grid used to disseminate information was that established by Eurostat. Information was facilitated only for those $1 \mathrm{~km}^{2}$ grids that contained at least one (main or second) dwelling.

Moreover, the geographic $\mathrm{x}$ and $\mathrm{y}$ coordinates of each dwelling were known, required to apply spatial models. With this information, distances to the city center or the coastline were calculated. Distance to the city center was geometrically acquired by transforming coordinates decimal grades into meters. Distance to the coastline was obtained with the ArcMap software. As the location variable, access to the tram system that connects towns with the city was also included. Table 1 shows variable definitions, sources and means.

Table 1. Variable definitions, means and SD

\begin{tabular}{|c|c|c|c|}
\hline $\begin{array}{l}\text { Variable } \\
\text { name }\end{array}$ & Definition & Mean & $\mathrm{SD}$ \\
\hline VINM & $\begin{array}{l}\text { Total appraisal value for } \\
\text { a multifamily residential } \\
\text { property }(€)\end{array}$ & 102664 & 78614 \\
\hline ANT_C & $\begin{array}{l}\text { Age corrected by all-round } \\
\text { alteration works (years) }\end{array}$ & 34 & 21 \\
\hline SADO & $\begin{array}{l}\text { Surface area taken by the } \\
\text { appraiser }\left(\mathrm{m}^{2}\right)\end{array}$ & 105 & 35 \\
\hline COST & $\begin{array}{l}\text { Construction costs estimated } \\
\text { by the appraiser }\left(€ / \mathrm{m}^{2}\right)\end{array}$ & 551 & 125 \\
\hline NUBA & Number of bathrooms & 1.61 & 0.59 \\
\hline NUDO & Number of bedrooms & 1.62 & 0.61 \\
\hline CALI & $\begin{array}{l}\text { Construction quality; values } \\
\text { from } 4 \text { to } 1 \text { (worse to better) }\end{array}$ & 3.01 & 1.19 \\
\hline CONS & $\begin{array}{l}\text { Conservation status of the } \\
\text { dwelling; values from } 4 \text { to } 1 \\
\text { (worse to better) }\end{array}$ & 2.62 & 1.28 \\
\hline MCTC & $\begin{array}{l}\text { Surface area of covered } \\
\text { terrace }\left(\mathrm{m}^{2}\right)\end{array}$ & 1.93 & 5.41 \\
\hline MCTD & $\begin{array}{l}\text { Surface area of uncovered } \\
\text { terrace }\left(\mathrm{m}^{2}\right)\end{array}$ & 1.92 & 7.36 \\
\hline NPLA & Number of storeys & 4.84 & 2.26 \\
\hline IZVE & $\begin{array}{l}1 \text { if a property has green } \\
\text { spaces ( } 7 \% \text { of flats) }\end{array}$ & 0.07 & 0.25 \\
\hline IPIS & $\begin{array}{l}1 \text { if a property has a } \\
\text { swimming pool ( } 9 \% \text { of flats) }\end{array}$ & 0.09 & 0.29 \\
\hline ICAL & $\begin{array}{l}1 \text { if a property has heating } \\
\text { ( } 24 \% \text { of flats) }\end{array}$ & 0.24 & 0.43 \\
\hline IAIR & $\begin{array}{l}1 \text { if a property has air } \\
\text { conditioning ( } 36 \% \text { of flats) }\end{array}$ & 0.36 & 0.48 \\
\hline IASC & $\begin{array}{l}1 \text { if a property has an } \\
\text { elevator ( } 71 \% \text { of flats) }\end{array}$ & 0.71 & 0.45 \\
\hline NGAR & $\begin{array}{l}1 \text { if a property has a parking } \\
\text { place ( } 3 \% \text { of flats) }\end{array}$ & 0.03 & 0.18 \\
\hline IECO: & $\begin{array}{l}1 \text { if is normative, and } 0 \\
\text { otherwise }\end{array}$ & 0.78 & 0.42 \\
\hline
\end{tabular}


End of Table 1

\begin{tabular}{|c|c|c|c|}
\hline $\begin{array}{l}\text { Variable } \\
\text { name }\end{array}$ & Definition & Mean & SD \\
\hline PEXN & $\begin{array}{l}\text { Percentage of the foreign } \\
\text { population born in Africa, } \\
\text { Central America, South } \\
\text { America, Asia, the Carib- } \\
\text { bean and Oceania }\end{array}$ & 0.06 & 0.04 \\
\hline PEXE & $\begin{array}{l}\text { Percentage of the foreign } \\
\text { residents population that is } \\
\text { European }\end{array}$ & 0.04 & 0.04 \\
\hline NEALT & $\begin{array}{l}\text { Percentage of residents with } \\
\text { a high level of education }\end{array}$ & 0.48 & 0.07 \\
\hline VVAC & Percentage of empty dwellings & 0.13 & 0.06 \\
\hline HAVI & Number of people per dwelling & 1.03 & 0.24 \\
\hline ALQ & Percentage of rented dwellings & 0.07 & 0.04 \\
\hline $\mathrm{C} 1$ & $\begin{array}{l}\text { City center }<0.5 \mathrm{~km}(1 \% \text { of } \\
\text { flats })\end{array}$ & 0.01 & 0.10 \\
\hline C2: & $\begin{array}{l}\text { City center }<2 \mathrm{~km} \text { and }> \\
0.5 \mathrm{~km}(14 \% \text { of flats }) \\
\end{array}$ & 0.14 & 0.34 \\
\hline P1: & $\begin{array}{l}\text { Less than } 100 \mathrm{~m} \text { to the beach } \\
(2 \% \text { of flats })\end{array}$ & 0.02 & 0.13 \\
\hline P2: & $\begin{array}{l}\text { Less than } 2 \mathrm{~km} \text { to the beach } \\
>100 \mathrm{~m}(10 \% \text { of flats })\end{array}$ & 0.10 & 0.29 \\
\hline $\begin{array}{l}\text { D1 } \\
\text { REN }\end{array}$ & $\begin{array}{l}\text { Less than } 1 \mathrm{~km} \text { to a tram } \\
\text { station }\end{array}$ & 0.67 & 0.47 \\
\hline $\begin{array}{l}\text { D2 } \\
\text { REN }\end{array}$ & $\begin{array}{l}\text { Less than } 2 \mathrm{~km} \text { to a tram } \\
\text { station }\end{array}$ & 0.12 & 0.33 \\
\hline $\begin{array}{l}\text { S01 a } \\
\text { S31 }\end{array}$ & $\begin{array}{l}1 \text { if the appraisal was } \\
\text { done by a company that } \\
\text { performed }>75 \text { houses }\end{array}$ & & \\
\hline SRES & $\begin{array}{l}1 \text { if the appraisal was done } \\
\text { by a company in the group } \\
\text { of } 10 \text { smaller companies }\end{array}$ & & \\
\hline $\mathrm{N}$ & Number of observations & 17,007 & \\
\hline
\end{tabular}

\subsection{Methods}

Consistently with the literature (Affuso et al., 2017; Brasington, 2004; Chegut et al., 2015), we used a hedonic model to examine the relationships between the appraisal value and the analyzed characteristics:

$$
y=\alpha+\sum_{1}^{N} \beta_{i} X_{i}+\sum_{1}^{M} \gamma_{j} D_{j}+\varepsilon,
$$

where: $y$ - property value in $€ ; X_{i}$ - continuous variables; $D_{j}$ - dichotomous variables; $N$ - number of continuous variables; $M$ - number of dichotomous variables; $\varepsilon$ - error.

We assumed that the appraisal value was in accordance with the intrinsic property characteristics, neighborhood socio-economic and demographic characteristics, distance to city center and the coastline, the company that made the appraisal and the spatial process.

The tests to analyze the autocorrelation, normality and heteroskedasticity of the hedonic models estimated by OLS were: Durbin-Watson, Jarque-Bera and BreuschPagan.

Whether spatial dependence existed was determined by Moran's I Index (Moran, 1950) and by Lagrange Multiplier (LM), by applying different spatial weights: distance, contiguity and k-nearest neighbors (KNN).
Spatial models were determined in a second step:

- The spatial lag model (SLM):

$$
\begin{aligned}
& y=\alpha+\rho W y+X \beta+D \gamma+u \\
& \mathrm{u} \sim \mathrm{N}\left(0, \sigma^{2} I_{n}\right),
\end{aligned}
$$

where: $\rho$ - coefficient of spatial correlation; $W$ - standardized spatial matrix; $u$ - spatial error.

- The spatial error model (SEM):

$$
y=\alpha+X \beta+D \gamma+u,
$$

where errors matrix $u$ follows a spatial autoregressive regression (SAR) process.

$$
u=\lambda W u+\varepsilon,
$$

where: $\lambda$ - coefficient of residuals spatial correlation; $\varepsilon-$ idiosyncratic errors matrix.

According to Anselin (1998), the estimation of models SLM and SEM cannot be done by OLS as this estimation would be inconsistent and/or inefficient, depending on the case. As a result, alternative methodologies of two types were sought: the first is maximum likelihood (ML) (Anselin, 1988), which is based on the hypothesis of the normality, independence and identically distributed error $\mathrm{u}$ term. One estimation by $\mathrm{ML}$ is based on strong assumptions which, if fulfilled, confer the model optimum properties (e.g., consistency and asymptotic efficiency); if these assumptions are violated, these optimum properties are lost. Therefore, heteroskedasticity cannot appear. The second methodological alternative to estimate models is generalized moments (GMM) (Kelejian \& Prucha, 1999), which does not require the normality assumption.

We use the adjusted ( $\mathrm{R}^{2}$ adjusted) determination coefficient and Akaike's information criterion (AIC) to test several functional forms for the hedonic price equation and the selected variables, and in models SLM and SEM by ML. The Student's $t$-test was also run with the coefficients of all the variables. In the models SLM and SEM estimated by the GMM, Spatial pseudo $\mathrm{R}^{2}$ was used, which is the approximate $\mathrm{R}^{2}$ estimation.

Spatial weights matrix $\mathrm{W}$ was obtained with distance and contiguity was symmetric, but not in the k-nearest neighbors case. This can be a problem when it is applied to the spatial models by ML. However, it is possible to obtain spatial models by applying non symmetric matrices in the GMM (Anselin, 1998; Kelejian \& Prucha, 1999).

- The spatial lag and error model (SLM-SEM).

The reason for this model lies in the circumstance that after estimating the SAR model, the spatial autocorrelation of residuals continued to appear (e.g., measured by Moran's I). So it was easier to eliminate this autocorrelation by jointly applying SLM and SEM.

The reduced error process (4) form is as follows:

$u=(I-\lambda W)^{-1} \varepsilon$.

If we substitute (5) in (2), we obtain:

$$
y=\alpha+\rho W y+\sum_{1}^{N} \beta_{i} X_{i}+\sum_{1}^{M} \gamma_{j} D_{j}+(I-\lambda W)^{-1} \varepsilon
$$




$$
y-\rho W y=\alpha+\sum_{1}^{N} \beta_{i} X_{i}+\sum_{1}^{M} \gamma_{j} D_{j}+(I-\lambda W)^{-1} \varepsilon .
$$

By multiplying both sides of the equation by $(I-\lambda W)$, we obtain:

$$
\begin{aligned}
& y=\alpha(I-\lambda W)+(\lambda+\rho) W y-\lambda \rho W^{2} y+ \\
& \sum_{1}^{N} \beta_{i} X_{i}(I-\lambda W)+\sum_{1}^{M} \gamma_{j} D_{j}(I-\lambda W)+\varepsilon .
\end{aligned}
$$

A problem arises with terms $\lambda$ and $\rho$ as they have no single solution because they are summed and multiplied to one another in the same formula.

The model is solved in exactly the same way as in the SEM case, with the only difference being that it contains endogenous variables $-\lambda \rho W^{2} \mathrm{y},-\lambda W \sum_{1}^{N} \beta_{i} X_{i}$ and $-\lambda W \sum_{1}^{M} \gamma_{j} D_{j}$

To calculate the parameters, first the generalized spatial two-phased least-squared estimator method (GS2SLS) was applied to estimate $\rho$ and the GMM to estimate $\lambda$.

If the normality and heteroskedasticity tests are negative, which means that the obtained estimators are not unbiased, and this can be solved by processing the HAC (Heteroskedasticity and Autocorrelation Consistent Standard Errors), and White and HET (Kelejian \& Prucha, 2010) estimations to deal with heteroskedasticity.

The GMM is one of the most modern methodologies to estimate parameters. It is based on estimating probability distribution parameters by calculating possible distribution values with which a better fit of the moments is obtained when data are analyzed. There are four moments in a normal distribution: mean, standard deviation, asymmetry and kurtosis. The data distribution might not be exactly the same as those in the data distribution, but the estimation is based on obtaining the moments of a distribution that most closely resembles the real distribution.

From a practical point of view, the GMM allows data processing problems to be solved which, as previously mentioned, are considered with the ML method as calculations that are much more complex (Kelejian \& Prucha, 1999).

The estimation process to estimate parameters is as follows:

- First the model estimation is obtained by either MCO or GS2SLS (if there are any endogenous variables) to thus obtain residuals, $u$. Using the initial regression model (3) and the errors vector (4), residuals $u$ and their spatial lags $\lambda$ are included in the equations of moments (5), and an initial estimation is obtained.

$\mathrm{m}=\mathrm{g}-\mathrm{G}\left(\begin{array}{c}\lambda \\ \lambda^{2}\end{array}\right)=0$.

- Second, the initial estimations, using the estimations of $\lambda$, which we call $\widehat{\lambda_{1}}$, are employed in a spatially weighted least-squared equation to obtain some new $\beta$ parameters. The technical details of this methodology are provided in detail in Kelejian and Prucha (2010).

To apply HAC, a Kernel weights matrix is required.

\section{Results}

Moran's I Index for the dwelling's appraisal value by apply-

\begin{tabular}{|c|c|c|}
\hline \multirow[b]{2}{*}{ Criterion } & \multicolumn{2}{|c|}{ Summary of the results } \\
\hline & Matrix $^{1}$ & Moran's I \\
\hline Distance & MIN_DIST & 0.008 \\
\hline Distance & DIST_1000 & 0.465 \\
\hline Distance & DIST_500 & 0.562 \\
\hline Contiguity & ADJ_1 & 0.665 \\
\hline Contiguity & ADJ_2 & 0.594 \\
\hline Contiguity & ADJ_30 & -0.094 \\
\hline $\mathrm{K}$ - nearest neighbors & KNN6 & 0.685 \\
\hline $\mathrm{K}$ - nearest neighbors & KNN10 & 0.662 \\
\hline $\mathrm{K}$ - nearest neighbors & KNN30 & 0.618 \\
\hline
\end{tabular}
ing the different spatial weight is offered in Table 2.

Table 2. Moran's I Index for the different weights matrices

As we can see, the weights matrix of distances with contiguity order 1 (Queen) gives good results $(\mathrm{I}=0.665)$, but the best results are given for the neighborhood criterion (particularly knn with 6 neighbors) $(\mathrm{I}=0.685)$.

The criterion that gives the worst results is distance because if we consider the minimum distance (so that all the dwellings have at least one neighbor), Moran's I shows an almost null spatial autocorrelation $(\mathrm{I}=0.008)$ (bimodal distribution is generated). The autocorrelation increases when we take shorter distances (which is logical), but "isles" appear in the weights and make the analysis complicated. Moreover, but no less important, this kind of weights means using an enormous amount of computing resources given the high matrix nxn density, and calculations become extremely complicated with roughly 5000 data. Anselin and Rey (2014) point out that calculation problems start arising with several thousands of data for both SLM and SEM.

For all these reasons, the distance weights matrix was ruled out, and the weights matrix with KNN6, 6 nearest neighbors and contiguity degree 1 were selected. However, this implies a problem that stems from the weights matrix's lack of symmetry for KNN6.

Table 3 includes the indicators of the hedonic models estimated by OLS by taking the property's appraisal value as the dependent variable (in its logarithmic form). Table 4 shows the spatial dependence diagnostics.

Table 3. Test of multicollinearity, heteroskedasticity, non normality and spatial dependence in OLS

\begin{tabular}{|l|l|c|c|}
\hline \multicolumn{2}{|l|}{} & $\beta$ & sign \\
\hline Autocorrelation & Durbin-Watson & 1.8079 & \\
\hline Normality & Jarque-Bera & & 0.000 \\
\hline Heteroskedasticity & Breusch-Pagan test & & 0.000 \\
\hline
\end{tabular}

5 MIN_DIST refers to the minimum distance so that all the observations have a neighbor, which is $12.9 \mathrm{~km}$. DIST_1000 and DIST_500 respectively refer to 1000 and 500 meters. ADJ_1 denotes contiguity degree 1 (all the nearest flats), ADJ_2 and ADJ_30 respectively represent contiguity degree 2 and 30 (all flats up to proximity degree $\mathrm{k}$, so that the number of neighbors varies depending on proximity); KNN6, KNN10 and KNN30 respectively refer to only 6,10 and 30 nearest neighbors. 
Table 4. Spatial dependence diagnostics

\begin{tabular}{|c|c|c|c|c|c|c|}
\hline \multirow[b]{3}{*}{ TEST } & \multicolumn{6}{|c|}{ WEIGHTS } \\
\hline & \multicolumn{3}{|c|}{ KNN6 } & \multicolumn{3}{|c|}{ Contiguity ADJ_1 } \\
\hline & $\mathrm{MI} / \mathrm{DF}$ & VALUE & n.c. & $\mathrm{MI} / \mathrm{DF}$ & VALUE & n.c. \\
\hline Moran's I (error) & 0.26 & 62.6803 & $* * *$ & 0,24 & 54.3513 & $* * *$ \\
\hline LM (lag) & 1 & 2667.7152 & $* * *$ & 1 & 2621.9507 & $* * *$ \\
\hline Robust LM (lag) & 1 & 706.0637 & $* * *$ & 1 & 779.6412 & $* * *$ \\
\hline LM (error) & 1 & 3889.1747 & $* * *$ & 1 & 2928.3063 & $* * *$ \\
\hline Robust LM (error) & 1 & 1927.5232 & $* * *$ & 1 & 1085.9968 & $* * *$ \\
\hline LM (SARMA) & 2 & 4595.2384 & $* * *$ & 2 & 3707.9475 & $* * *$ \\
\hline
\end{tabular}

${ }^{* * *}$ The test shows that spatial dependence exists at the $99 \%$ significance level.

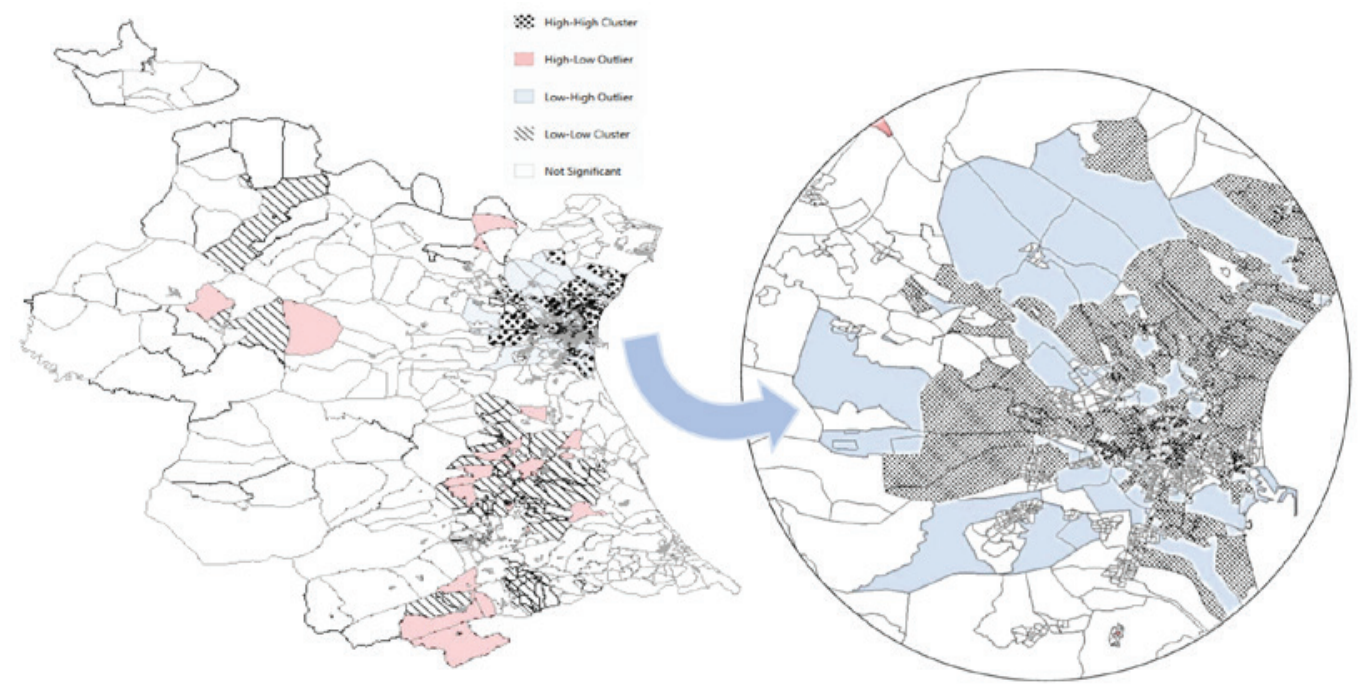

Figure 2. LISA (Local Indicators of Spatial Association) OLS Std_Residuals

All the tests indicate that spatial dependence exists.

Figure 2 shows the Local Indicators of Spatial Association of the OLS standard errors, geographically distributed in census sections (secciones censales). High residual values are located around the city of Valencia (HH values), while Low residuals clusters are fewer and located inside the province.
A specification of the OLS hedonic model is provided in Table 5, along with the spatial models using the contiguity degree 1 weights matrices estimated by ML. In them the dependent variable is the value that the property takes in its logarithmic form. Appraisal company S14 is used as a witness in all the analyses.

Table 5. Model OLS, models SLM and SEM estimated by ML and model SLM-SEM estimated by the GMM with the contiguity degree 1 matrices

\begin{tabular}{|c|c|c|c|c|}
\hline \multirow{2}{*}{$\frac{\text { Contiguity_1 }}{\text { Variables }}$} & \multicolumn{4}{|c|}{ Coefficients } \\
\hline & OLS & SLM & SEM & SLM+SEM (GMM) \\
\hline Constant & $6.1^{\star * \star}(0)$ & $3.34^{\star * *}(0)$ & $5.65^{\star * \star}(0)$ & $3.32^{\star * *}(0)$ \\
\hline LN_ANT_C & $0.16^{* * *}(0)$ & $0.17^{\star * *}(0)$ & $0.2^{\star * \star}(0)$ & $0.18^{\star * \star}(0)$ \\
\hline LN_ANT_C_2 & $-0.04^{\star * \star}(0)$ & $-0.04^{\star \star \star}(0)$ & $-0.05^{\star \star \star}(0)$ & $-0.05^{\star \star \star}(0)$ \\
\hline LN_SADO & $-0.36^{* * *}(0)$ & $-0.21^{\star * *}(0.04)$ & $0.17^{\star \star}(0.1)$ & $-0.03(0.86)$ \\
\hline LN_SADO_2 & $0.14^{\star * \star}(0)$ & $0.12^{\star * *}(0)$ & $0.08^{\star \star \star}(0)$ & $0.1^{\star * \star}(0)$ \\
\hline COST & $0.66^{* * \star}(0)$ & $0.58^{\star \star \star}(0)$ & $0.54^{\star \star \star}(0)$ & $0.56^{\star * \star}(0)$ \\
\hline NUDO & $0.08^{\star * \star}(0)$ & $0.07^{\star * *}(0)$ & $0.07^{\star \star \star}(0)$ & $0.07^{\star \star \star}(0)$ \\
\hline CALI & $-0.28^{\star * \star}(0)$ & $-0.23^{\star \star \star}(0)$ & $-0.22^{\star * \star}(0)$ & $-0.22^{\star \star \star}(0)$ \\
\hline CONS & $-0.19^{* * *}(0)$ & $-0.19^{\star \star \star}(0)$ & $-0.19^{\star * *}(0)$ & $-0.19^{\star \star \star}(0)$ \\
\hline
\end{tabular}


End of Table 5

\begin{tabular}{|c|c|c|c|c|}
\hline \multirow{2}{*}{$\frac{\text { Contiguity_1 }}{\text { Variables }}$} & \multicolumn{4}{|c|}{ Coefficients } \\
\hline & OLS & SLM & SEM & SLM+SEM (GMM) \\
\hline MCTC & $-0.01^{\star * \star}(0)$ & $-0.01^{\star * \star}(0)$ & $-0.01^{\star * \star}(0)$ & $-0.01^{\star \star \star}(0)$ \\
\hline MCTD & $0.02^{\star * *}(0)$ & $0.02^{* * *}(0)$ & $0.02^{\star * *}(0)$ & $0.02^{* * *}(0)$ \\
\hline NPLA & $0.02^{\star * \star}(0)$ & $0.01^{\star * *}(0)$ & $0.01^{\star * \star}(0.03)$ & $0.01^{\star * \star}(0.04)$ \\
\hline IZVE & $0.05^{\star * *}(0)$ & $0.02^{\star * \star}(0.05)$ & $0.03^{* * *}(0)$ & $0.02^{* * *}(0.05)$ \\
\hline IPIS & $0.08^{\star * *}(0)$ & $0.04^{* * *}(0)$ & $0.05^{\star * \star}(0)$ & $0.04^{\star * *}(0)$ \\
\hline ICAL & $0.04^{* * *}(0)$ & $0.04^{* * *}(0)$ & $0.04^{* * *}(0)$ & $0.04^{* * *}(0)$ \\
\hline IAIR & $0.04^{\star * \star}(0)$ & $0.05^{\star \star \star}(0)$ & $0.04^{\star * *}(0)$ & $0.04^{\star * \star}(0)$ \\
\hline IASC & $0.2^{\star \star \star *}(0)$ & $0.17^{\star * *}(0)$ & $0.18^{* * *}(0)$ & $0.17^{\star * *}(0)$ \\
\hline IECO & $0.02^{* * *}(0)$ & $0.02^{* * *}(0)$ & $0.02^{\star \star \star}(0)$ & $0.02^{\star \star \star}(0)$ \\
\hline PEXN & $-0.36^{\star * *}(0)$ & $0(0.95)$ & $-0.27^{\star \star *}(0)$ & $0(0.97)$ \\
\hline PEXE & $-0.76^{\star * \star}(0)$ & $-0.53^{\star * \star}(0)$ & $-0.68^{\star * *}(0)$ & $-0.54^{\star * \star}(0)$ \\
\hline NEALT & $0.5^{\star \star *}(0)$ & $0.34^{* * *}(0)$ & $0.48^{* * *}(0)$ & $0.36^{* * *}(0)$ \\
\hline VVAC & $-0.35^{\star * \star}(0)$ & $-0.26^{\star * *}(0)$ & $-0.34^{\star * \star}(0)$ & $-0.27^{\star \star \star}(0)$ \\
\hline HAVI & $-0.35^{\star * *}(0)$ & $-0.28^{\star * \star}(0)$ & $-0.34^{* * *}(0)$ & $-0.29^{\star \star \star}(0)$ \\
\hline ALQ & $1.75^{\star * *}(0)$ & $1.25^{\star * \star}(0)$ & $1.54^{\star * \star}(0)$ & $1.27^{\star \star *}(0)$ \\
\hline $\mathrm{C} 1$ & $0.63^{* * *}(0)$ & $0.36^{* * *}(0)$ & $0.66^{* * *}(0)$ & $0.39^{* * *}(0)$ \\
\hline $\mathrm{C} 2$ & $0.27^{\star \star \star}(0)$ & $0.17^{\star \star *}(0)$ & $0.3^{\star * \star}(0)$ & $0.19^{\star * \star}(0)$ \\
\hline $\mathrm{P} 1$ & $0.38^{* * *}(0)$ & $0.32^{\star * *}(0)$ & $0.36^{* * *}(0)$ & $0.33^{\star * *}(0)$ \\
\hline $\mathrm{P} 2$ & $0.2^{\star \star \star}(0)$ & $0.17^{\star * \star}(0)$ & $0.2^{\star * \star}(0)$ & $0.18^{\star \star *}(0)$ \\
\hline D1_REN & $0.1^{\star * *}(0)$ & $0.09^{* * *}(0)$ & $0.09^{* * *}(0)$ & $0.09^{* * *}(0)$ \\
\hline D2_REN & $0.05^{\star * \star}(0)$ & $0.04^{* * *}(0)$ & $0.05^{\star \star \star}(0)$ & $0.04^{\star * *}(0)$ \\
\hline S01 & $0.38^{* * *}(0)$ & $0.32^{\star * *}(0)$ & $0.25^{\star * \star}(0)$ & $0.28^{\star * *}(0)$ \\
\hline S07 & $-0.23^{\star * \star}(0)$ & $-0.2^{\star \star \star}(0)$ & $-0.22^{\star * \star}(0)$ & $-0.21^{\star * \star}(0)$ \\
\hline S08 & $-0.26^{\star * *}(0)$ & $-0.23^{\star * *}(0)$ & $-0.22^{\star * \star}(0)$ & $-0.22^{\star * *}(0)$ \\
\hline S09 & $-0.03(0.83)$ & $-0.01(0.95)$ & $-0.04(0.78)$ & $-0.02(0.66)$ \\
\hline S10 & $0.09^{* * *}(0)$ & $0.09^{* * *}(0)$ & $0.07^{\star \star *}(0)$ & $0.08^{\star * \star}(0)$ \\
\hline S11 & $-0.31^{\star \star \star}(0)$ & $-0.28^{\star * \star}(0)$ & $-0.28^{\star \star \star}(0)$ & $-0.28^{\star \star \star}(0)$ \\
\hline S12 & $-0.29^{* * *}(0)$ & $-0.26^{\star * *}(0)$ & $-0.28^{\star * \star}(0)$ & $-0.27^{\star \star \star}(0)$ \\
\hline S15 & $-0.22^{\star * *}(0)$ & $-0.21^{\star * \star}(0)$ & $-0.23^{\star * *}(0)$ & $-0.22^{\star * *}(0)$ \\
\hline S16 & $-0.25^{\star * \star}(0)$ & $-0.23^{\star * *}(0)$ & $-0.23^{\star * \star}(0)$ & $-0.23^{\star * \star}(0)$ \\
\hline S17 & $-0.15^{\star * \star}(0)$ & $-0.13^{\star * *}(0)$ & $-0.14^{\star * *}(0)$ & $-0.13^{\star * *}(0)$ \\
\hline S18 & $-0.13^{\star * *}(0)$ & $-0.11^{\star * *}(0)$ & $-0.12^{\star * *}(0)$ & $-0.11^{\star * *}(0)$ \\
\hline S20 & $-0.17^{\star \star \star}(0)$ & $-0.14^{\star \star \star}(0)$ & $-0.14^{\star * \star}(0)$ & $-0.13^{\star \star \star}(0)$ \\
\hline S23 & $-0.17^{\star \star *}(0)$ & $-0.15^{\star * *}(0)$ & $-0.16^{* * *}(0)$ & $-0.15^{\star * \star}(0)$ \\
\hline S25 & $-0.39^{* * \star}(0)$ & $-0.35^{\star * \star}(0)$ & $-0.35^{\star * \star}(0)$ & $-0.35^{\star * \star}(0)$ \\
\hline S26 & $-0.19^{\star * *}(0)$ & $-0.17^{\star * *}(0)$ & $-0.18^{\star * *}(0)$ & $-0.18^{\star * *}(0)$ \\
\hline S27 & $-0.21^{\star \star \star}(0)$ & $-0.21^{\star * \star}(0)$ & $-0.23^{\star \star \star}(0)$ & $-0.23^{\star \star \star}(0)$ \\
\hline S28 & $-0.24^{\star * *}(0)$ & $-0.21^{\star * *}(0)$ & $-0.21^{\star * *}(0)$ & $-0.21^{\star * *}(0)$ \\
\hline S29 & $-0.17^{\star \star \star}(0)$ & $-0.17^{\star \star \star}(0)$ & $-0.18^{\star * \star}(0)$ & $-0.18^{\star \star \star}(0)$ \\
\hline $\mathrm{S} 30$ & $-0.24^{\star * \star}(0)$ & $-0.22^{\star * *}(0)$ & $-0.24^{\star * \star}(0)$ & $-0.23^{\star * *}(0)$ \\
\hline S31 & $-0.17^{\star \star *}(0)$ & $-0.14^{\star * \star}(0)$ & $-0.15^{\star * \star}(0)$ & $-0.14^{\star \star \star}(0)$ \\
\hline SRES & $-0.2^{\star * \star}(0)$ & $-0.19^{\star * *}(0)$ & $-0.21^{\star * \star}(0)$ & $-0.2^{\star * *}(0)$ \\
\hline$\rho$ & $0(0)$ & $0.27^{\star \star *}(0)$ & $0(0)$ & $0.24^{\star \star \star}(0)$ \\
\hline$\lambda$ & $0(0)$ & $0(0)$ & $0.51^{\star * *}(0)$ & $0.25^{\star * *}(0)$ \\
\hline $\mathrm{R}^{2}$ adjusted & 0.8392 & 0.8614 & 0.8669 & 0.8605 \\
\hline AIC & 201.55 & -2052.25 & -2088.44 & \\
\hline
\end{tabular}

Level of significance ${ }^{\star \star} 95 \%$; ${ }^{\star} 90 \%$. P-value in parentheses. 
The spatial models that use the contiguity degree 1 weights matrices estimated by the GMM, and the models with the spatial K-nearest neighbors weights matrix, are employed, with a spatial pseudo $\mathrm{R}^{2}$ between 0.8343 and 0.86673 and very similar results.

The best model is SEM, obtained by ML and the contiguity weights because it presents the highest adjusted $\mathrm{R}^{2}$ (0.8669) and the lowest AIC (-2088.44).

In the analyzed models, all the hedonic variables are always significant, except for the non-European population (PEXN), which, in some cases, does not even reach $90 \%$.

Table 6. Coefficients of the appraisers' variables retransformed from the SEM model by ML

\begin{tabular}{|c|c|c|c|}
\hline Company & $\begin{array}{c}\text { Original } \\
\text { coefficients } \\
\gamma_{j}\end{array}$ & $\begin{array}{c}\text { Retransformed } \\
\text { coefficients } \\
e^{1^{*} \gamma_{j}}-1\end{array}$ & N.S \\
\hline S01 & 0.60 & 0.83 & $* * *$ \\
\hline S07 & 0.13 & 0.14 & $* * *$ \\
\hline S08 & 0.13 & 0.14 & $* * *$ \\
\hline S10 & 0.42 & 0.52 & $* * *$ \\
\hline S11 & 0.07 & 0.07 & $* * *$ \\
\hline S12 & 0.07 & 0.07 & $* * *$ \\
\hline S14 & 0.35 & 1.42 & $* * *$ \\
\hline S15 & 0.12 & 0.13 & $* * *$ \\
\hline S16 & 0.12 & 0.24 & $* * *$ \\
\hline S17 & 0.21 & 0.26 & $* * *$ \\
\hline S18 & 0.23 & 0.23 & $* * *$ \\
\hline S20 & 0.21 & 0.21 & $* * *$ \\
\hline S23 & 0.19 & 0.00 & $* * *$ \\
\hline $\mathrm{S} 25^{6}$ & 0.00 & 0.00 & $* * *$ \\
\hline S26 & 0.17 & 0.18 & $* * *$ \\
\hline S27 & 0.12 & 0.12 & $* * *$ \\
\hline S28 & 0.14 & 0.15 & $* * *$ \\
\hline S29 & 0.17 & 0.19 & $* * *$ \\
\hline S30 & 0.12 & 0.12 & $* * *$ \\
\hline S31 & 0.20 & 0.22 & $* * *$ \\
\hline SRES & 0.14 & 0.15 & $* * *$ \\
\hline
\end{tabular}

Moreover in all the models, the coefficients of the variables, except for variable PEXN, are similar and take the same sign.

Significant differences were obtained in all the models among the appraisal companies (save S09) in relation to witness company S14.

Table 6 contains the coefficients for all the companies, obtained according to the SEM model estimated by ML with the contiguity degree 1 weight matrix.

As we can see, the coefficients that correspond to the companies show statistically significant differences, and in relation to that with a lower coefficient (S25), they range between $+83 \%$ of the valuation and $+0 \%$. The mean difference is $22 \%$.

One third of companies ( 8 of 22) exceed the overvaluation mean.

When grouping into over-valuation intervals $(<10 \%$; from $10 \%$ to $25 \%$; from $25 \%$ to $50 \%$ and $>50 \%$ ), we observe that $64 \%$ of companies value between $10 \%$ and $25 \%$ more than the company selected to make the comparison does (see Figure 3).

Table 7 shows how the companies that are grouped into four size groups are distributed, according to the mean over-valuation level. Group 4 represents the smallest companies and groups 10 companies, whose mean overvaluation is $15 \%$. The other groups comprise seven com-

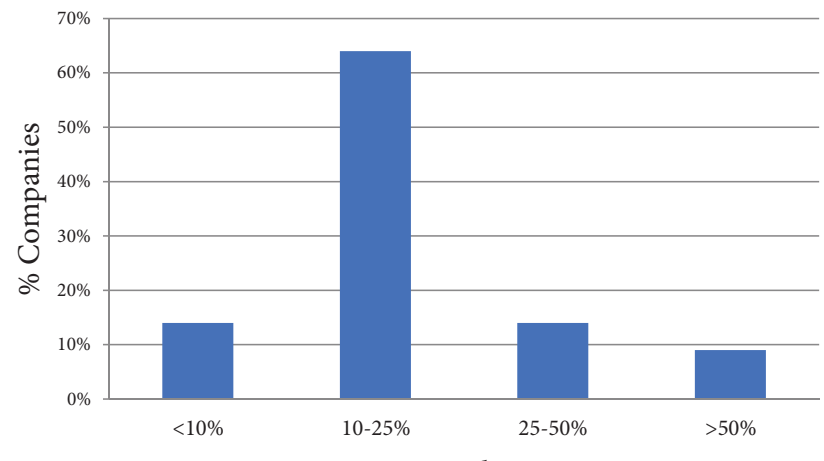

\% Overvaluation

Figure 3. Histogram of the $\%$ of companies according to overvaluation levels

Table 7. Distribution of appraisal companies according to number of appraisals made, overappraisals and SEM model coefficients

\begin{tabular}{|l|c|c|c|c|c|c|c|}
\hline \multicolumn{1}{|c|}{ Company size } & \multicolumn{6}{|c|}{ Over-valuation } \\
\hline & $\begin{array}{c}<10 \% \\
(\text { low })\end{array}$ & $\begin{array}{c}10-25 \% \\
\text { (moderate) }\end{array}$ & $\begin{array}{c}25-50 \% \\
\text { (high) }\end{array}$ & $\begin{array}{c}>50 \% \text { (very } \\
\text { high) }\end{array}$ & Mean & $\begin{array}{c}\text { SEM model } \\
\text { coeff. }\end{array}$ & $\begin{array}{c}\text { No. } \\
\text { companies }\end{array}$ \\
\hline 1 large (> 1250 appraisals) & $14.3 \%$ & $57.1 \%$ & $28.6 \%$ & & $19 \%$ & $0.52 \%(0.25)$ & 7 \\
\hline 2 medium (500-1250 appraisals) & $28.6 \%$ & $71.4 \%$ & & & $13 \%$ & $0.0 \%{ }^{* * *}(0)$ & 7 \\
\hline 3 small (100-500 appraisals) & & $57.1 \%$ & $14.3 \%$ & $28.6 \%$ & $35 \%$ & $8.91 \%{ }^{* * *}(0)$ & 7 \\
\hline 4 micro (<100 appraisals) & & $100.0 \%$ & & & $15 \%$ & $-1.02 \%(0.56)$ & 10 \\
\hline Total & $14 \%$ & $64 \%$ & $14 \%$ & $9 \%$ & & & $100 \%$ \\
\hline
\end{tabular}

${ }^{6}$ In this case we take S25 as the company to compare with because its presents a lower regression coefficient, while the other coefficients are $>0$. 
panies each. In all cases, the most frequent over-valuation levels are moderate, except for group 3 (small companies) with $43 \%$ which implies high or very high over-valuation levels; $28.6 \%$ of large companies obtain high over-valuation levels (25-50\%).

The mean over-valuation level of each group is $19 \%$ for large-sized companies, 13\% for medium-sized ones, 35\% for small-sized ones and 15\% for micro-companies. These results are in line with that pointed out and reveal that the highest over-valuation levels go to small-sized companies (defined as those that make 100-500 appraisals).

\section{Discussion}

The contribution to the academic literature lies precisely in this being the first work to jointly analyze the data of all the valuations made for financing purposes over a 1 -year period and in a given region. To date all the other works conducted in Spain have been related with a single appraisal company (García \& Raya, 2011) or with a realestate intermediary (Akin et al., 2014; Montalvo \& Raya, 2017), which meant that making comparisons among them was impossible. What this suggests is that when the data of valuations from a single information source are analyzed, they can provide biased results that derive from either human judgment or the appraiser's guidelines.

In line with other works (Affuso et al., 2017; Brasington, 2004; Chegut et al., 2015; Zhang et al., 2015), spatial models provide better results than hedonic models. Nonetheless, the differences between them are small. All the coefficients of the variables provide coherent results, but some results need explaining.

When presenting the coefficients of a higher magnitude to determine the property's appraisal value, the most relevant variables are basically those that affect the socioeconomic setting; European foreign population, level of education, empty dwellings, mean number of tenants and rented dwellings in the area. This result differs to the view of Aspachs-Bracons and Rabanal (2010), who consider that one of the main factors that could be behind the peak observed in residential properties in Spain is demographic factors related with immigration and changes in the composition of homes. According to our study, the non European foreign population was not significant or gave a negative coefficient in the models. Save some very delimited areas (as in the city of Valencia), this might be due to this population being spread out all over the province, except in coastline areas where it does not appear. Conversely, the European foreign population has a negative coefficient. This is because the higher concentrations of European populations are non-Schengen nationalities, whose general profile is a medium-low level. These coefficients imply that in the cases with a higher concentration of foreigners, relative prices are lower in relation to the setting. However in some isolated areas, concentrations of different European populations to the previous one can be found (particularly the English), which would have a dif- ferent effect, but the relative weight in the province is lower. Thus the regressors show an inverse relation to price.

We have ratified the importance of location in the hedonic regression, as demonstrated by García and Raya (2011), although it has been measured differently through education in a given area. We find that a shorter distance to the coastline means a higher purchase-sale price for residential properties. In our study the prices with a shorter distance of 100 meters from a beach obtain $20 \%$ higher prices than those obtained for distances between 100 meters and $2 \mathrm{~km}$, but only for the location factor, which agrees with the retransformed coefficients difference ${ }^{7}$.

Regarding distance to city center, we also observe that more centrally located dwellings tend to be more expensive than those at a longer distance to the center. This result coincides with Chasco and Le Gallo (2013), who obtained statistically significant results for proximity to the main axes, distance to CBD and for distance to large parks in order to analyze the impact of pollution and noise on the purchase-sale price of dwellings in the city of Madrid. However, their study referred only to central Madrid, and the idiosyncrasy of Madrid also differs to Valencia. The value of a residential property being located first in line to the beach is also almost twice the price of those located at a further distance to these areas. Indeed, in the selected model, regressors give a value of 0.66 and 0.34 in the city center and location first in line to the beach, versus 0.30 and 0.18 for locations not in the city center and second in line to the beach.

Just as Salon et al. (2014) found in China, the existence of a tram service in the towns surrounding the city influences the price of dwellings. The price of the housing located at a distance from a tram stop shorter than $1 \mathrm{~km}$ increases by $10 \%$, while those located less than $2 \mathrm{~km}$ from a tram stop increase by $5 \%$ compared to other dwellings located in towns of the same province.

This led us to establish that location is a much more important variable when it comes to valuing a dwelling than its intrinsic characteristics, at least for dwellings with similar basic characteristics. Indeed some characteristic variables of dwellings influence the value less. The regressors of these variables take values of 0.18 if the building has an elevator, 0.04 if there is air conditioning and, therefore, influence the value less than location factors. The coefficient is negative with covered terraces. This is apparently due to a covered terrace normally being valued as more usable surface area because a covered terrace surface area is calculated at $50 \%$ as the dwelling having more surface area. Thus a negative coefficient is obtained by valuing this surface area to a lesser extent than other surface areas. Number of bathrooms is not significant, which is possibly due to its correlation with the dwelling's surface area, and the same applies to number of parking places as most dwellings (97\%) report none.

$7 \mathrm{P} 1=0,34$ and $\mathrm{P} 2=0.18$. If we retransform the coefficients, then $\mathrm{P} 1=e^{0,34}$ and $\mathrm{P} 2=e^{0,18}$ 
Nor does the legal purpose of appraisals have a strong influence. Regarding appraisals in accordance with Ministerial Order ECO/805/2003 (78\% of evaluations were for mortgages), this dummy variable coefficient is positive, but only contributes $2.8 \%$ to the property's value. This result might be a surprising one as such valuations should be more conservative. Nonetheless, it can be interpreted that, on the one hand, the difference that this coefficient gives is limited ( $2.8 \%$ of the property's value) and, on the other hand, as these appraisals are for banking purposes, there is a tendency for more pressure from both customers and banks.

Regarding the main aspect of this study, we verified the influence of appraisal companies on values. Significant differences among them are found, which can be as much as $83 \%$ of the value depending on which company valued it. Of all the analyzed companies, $64 \%$ over-value between $10 \%$ and $25 \%$ compared to the company that gives the lowest values. The data reveal that the higher over-valuation levels are shown for small-sized companies (which make 100-500 valuations/year), where almost half the companies obtain high or very high over-valuation levels. No medium-sized or micro-company obtains high overvaluation levels, while two companies in the large-sized group (28.6\%) present high over-valuation levels.

The mean over-valuation in small-sized companies is higher, with $35 \%$ versus a mean of $22 \%$, which reinforces what has been pointed out.

These study findings may be an empirical contribution to this literature, which has been primarily survey- and experiment-based. It would be necessary to consider the possibility that the model could be miscalibrated, but we think this is not the case because the results of the obtained models are all in line in magnitude and sign terms. Besides, the selected model, which gave the best fit, generally shows some parameter values that are intermediate compared to those of the other models.

Moreover, the population was separated into several divisions to determine if differences among the parameters appeared. The results obtained from the cross validation show that the parameter values were similar and, thus, no model miscalibration problems appeared.

Furthermore to verify these results, a new SEM model was performed by substituting the appraisal companies' dummy variables for four dummy variables depending on the size of the company. The results of this new model were similar to the SEM model included in Table 5, but with an adjusted $\mathrm{R}^{2}$ below 0.84 and an AIC above 157.07. Thus the initial analysis was left with the appraisal companies' dummy variables.

Nonetheless Table 7 includes the coefficients of the SEM model with the sizes variables. The higher coefficient, 0.0891 , refers to small companies (significance level above $99 \%$ ). The very small companies coefficient is -0.0102 , and the Bigger companies one is 0.0052 . Medium companies are the benchmark dummy variable.

Although the measure is not comparable, these results agree with those obtained in other works conducted in
Spain (García Montalvo, 2009; Akin et al., 2014), which confirms that increased appraisals exist for purchase-sale values of around $29 \%$.

Nonetheless, it is worth stressing that this study differs from those by Chinloy et al. (1997) and Cho and Megbolugbe (1996), which compared property valuations with purchase-sale prices. In our case, the obtained over-valuation levels are not a measure of a higher value in absolute values over the "real" market value because, due to different purposes or other circumstances, the basis of the comparison can be undervalued. Although we are unaware if a transaction has taken place and, if so, its final price, a difference of up to $83 \%$ indicates a high degree of over-appraisal. We found that, although the results do not point out that over-appraising is a generalized practice, some appraisal companies systematically maintain a higher level for their valuations than others. Montalvo and Raya (2017) argue that the manipulation of loan to appraisal values, due to the ownership of appraisal companies by financial institutions, has been a determining cause of the challenges that the Spanish banking system has faced in recent years. Moreover in Spain, however, over-appraisal was an important driver of the housing bubble as it was used to open the market for borrowers with financial constraints. This fact has major implications for macroeconomic policies given the marked interrelations between financial markets and real-estate agencies because increasing valuations allow the amount of credit to be increased per financed dwelling owing to the $80 \%$ LTV ratio, which is currently favoured by very low rates. Thus Montalvo and Raya (2017) propose the notion that recovering the effectiveness of the LTV is to link the value used for the LTV ratio to the price, as reflected on the title kept at the Property Registry.

Nonetheless, it is worth stressing that this study differs from those by Chinloy et al. (1997) and Cho and Megbolugbe (1996), which compared property valuations with purchase-sale prices. In our case, the obtained overvaluation levels are not a measure of a higher value in absolute values over the "real" market value because, due to different purposes or other circumstances, the basis of the comparison can be undervalued.

\section{Conclusions}

The validity of spatial models to value dwellings for mortgage purposes has been demonstrated for the province of Valencia. The sample should be extended to other regions in Spain and for other years in order to validate the obtained results. Both the characteristics of dwellings and socio-economic and location factors influence mortgage values. Although it has not been possible to determine the differences with the purchase-sale value given the nature of the analyzed data, and also due to the fact that purchase-sale data are missing, it has been verified that the appraisal value differs depending on the company that makes the appraisal. It has been shown that company size somewhat influences values as small-sized ones present 
higher over-valuation levels, which confirms the weak situation they are in. Another analysis is necessary to be able to conclude a possible over-valuation incentive. Perhaps it is a matter of the smaller that companies are, the less they withstand pressure from customers and stakeholders to over-value. Perhaps company size grows if they give way to these pressures. If so, subordinating customers could mean unstable business for companies, which is not generally the case in practice.

So it is evident that other factors other than company size exist, such as interacting with other stakeholders, societal organization and internal control, or even the company's idiosyncrasy, which also influences if overvaluations exist. All this implies a high risk in mortgage securities, which can put the survival of banks at risk. Therefore, as stated by Lacour-Little and Malpezzi (2003), it is necessary to develop quality appraisal measures now more than ever while mortgage credits are rising because the Spanish economy is reactivating.

\section{References}

Affuso, E., Cummings, J. R., \& Le, H. (2017). Wireless towers and home values: an alternative valuation approach using a spatial econometric analysis. Journal of Real Estate Finance and Economics, 56(4), 653-676.

https://doi.org/10.1007/s11146-017-9600-9

Agnello, L., \& Schuknecht, L. (2011). Booms and busts in housing markets: determinants and implications. Journal of Housing Economics, 20, 171-190. https://doi.org/10.1016/j.jhe.2011.04.001

Akin, O., Montalvo, J. G., Garcia Villar, J., Peydro, J. L., \& Raya, J. M. (2014). The real estate and credit bubble: evidence from Spain. SERIEs, 5(2-3), 223-243. https://doi.org/10.1007/s13209-014-0115-9

Amidu, A. R., \& Aluko, B. T. (2007). Client influence in residential property valuations: an empirical study. Property Management, 25(5), 447-461. https://doi.org/10.1108/02637470710824720

Anselin, L. (1988). Spatial econometrics: methods and models. Kluwer Academic Publishers, Dordrecht, The Netherlands. https://doi.org/10.1007/978-94-015-7799-1

Anselin, L. (1998). Exploratory spatial data analysis in a geocomputational environment. Geocomputation, a Primer (pp. 77-94). Wiley, New York.

Anselin, L., \& Rey, S. J. (2014). Modern spatial econometrics in practice: a guide to GeoDa, GeoDaSpace and PySAL. GeoDa Press LLC.

Aspachs-Bracons, O., \& Rabanal, P. (2010). The drivers of housing cycles in Spain. SERIEs, 1(1-2), 101-130. https://doi.org/10.1007/s13209-009-0010-y

Baffour Awuah, K. G., \& Gyamfi-Yeboah, F. (2017). The role of task complexity in valuation errors analysis in a developing real estate market. Journal of Property Research, 34(1), 54-76. https://doi.org/10.1080/09599916.2017.1315444

Belsky, E., Can, A., \& Megbolugbe, I. (1998). A Primer on geographic information systems in mortgage finance. Journal of Housing Research, 9(1), 5-31.

Borst, R., \& McCluskey, W. (2007). Comparative evaluation of the comparative sales method with geostatistical valuation models. Pacific Rim Property Research Journal, 13(1), 106-129. https://doi.org/10.1080/14445921.2007.11104225
Bowcock, P. (2015). A discussion paper on valuations for mortgage and the level of house prices. International Journal of Housing Markets and Analysis, 8(1), 27-35.

https://doi.org/10.1108/IJHMA-07-2014-0024

Brasington, D. M. (2004). House prices and the structure of local government: an application of spatial statistics. Journal of Real Estate Finance and Economics, 29(2), 211-231.

https://doi.org/10.1023/B:REAL.0000035311.59920.74

Can, A. (1990). The measurement of neighborhood dynamics in urban house prices. Economic Geography, 66(3), 254-272. https://doi.org/10.2307/143400

Can, A. (1992). Specification and estimation of hedonic housing price models. Regional Science and Urban Economics, 22(3), 453-474. https://doi.org/10.1016/0166-0462(92)90039-4

Cerruti, E., Dagher, J., \& Dell'Ariccia, G. (2017). Housing finance and real-estate booms: a cross-country perspective. Journal of Housing Economics, 38, 1-13. https://doi.org/10.1016/j.jhe.2017.02.001

Chasco, C., \& Le Gallo, J. (2013). The Impact of objective and subjective measures of air quality and noise on house prices: a multilevel approach for Downtown Madrid. Economic Geography, 89(2), 127-148.

https://doi.org/10.1111/j.1944-8287.2012.01172.x

Chegut, A. M., Eichholtz, P. M. A., \& Rodrigues, P. J. M. (2015). Spatial dependence in international office markets. Journal of Real Estate Finance and Economics, 51(2), 317-350.

https://doi.org/10.1007/s11146-014-9484-x

Chinloy, P., Cho, M., \& Megbolugbe, I. F. (1997). Appraisals, transaction incentives and smoothing. Journal of Real Estate Finance and Economics, 14, 89-111.

https://doi.org/10.1023/A:1007772018106

Cho, M., \& Megbolugbe, I. F. (1996). An empirical analysis of property appraisal and mortgage redlining. Journal of Real Estate Finance and Economics, 13, 45-55.

https://doi.org/10.1007/BF00174550

Crosby, N., Lizieri, C., \& McAllister, P. (2010). Means, motive and opportunity? Disentangling client influence on performance measurement appraisals. Journal of Property Research, 27(2), 181-201. https://doi.org/10.1080/09599916.2010.499014

Dubin, R. (1998). Estimation of regression coefficients in the presence of spatially autocorrelated error terms. The Review of Economics and Statistics, 70(3), 466-474.

https://doi.org/10.2307/1926785

Gallimore, P., \& Wolverton, M. (2000). The objective in valuation: a study of the influence of client feedback. Journal of Property Research, 17(1), 47-57.

https://doi.org/10.1080/095999100368010

García, J., \& Raya, J. M. (2011). Price and income elasticities of demand for housing characteristics in the city of Barcelona. Regional Studies, 45(5), 597-608.

https://doi.org/10.1080/00343401003713381

García Montalvo, J. (2009). Financiación inmobiliaria, burbuja crediticia y crisis financiera: lecciones a partir de la recesión de 2008-2009. Papeles de Economía Española, 122, 66-87.

Hordijk, A., \& Van de Ridder, W. (2005). Valuation model uniformity and consistency in real estate indices: the case of the Netherlands. Journal of Property Investment \& Finance, 23(2), 165-181. https://doi.org/10.1108/14635780510584355

Jimeno, J. F., \& Santos, T. (2014). The crisis of the Spanish economy. SERIEs, 5, 125-141. https://doi.org/10.1007/s13209-014-0116-8

Kelejian, H. H., \& Prucha, I. R. (1999). A generalized moments estimator for the autoregressive parameter in a spatial model. International Economic Review, 40(2), 509-533.

https://doi.org/10.1111/1468-2354.00027 
Kelejian, H. H., \& Prucha, I. R. (2010). Specification and estimation of spatial autoregressive models with autoregressive and heteroskedastic disturbances. Journal of Econometrics, 157(1), 53-67. https://doi.org/10.1016/j.jeconom.2009.10.025

Klamer, P., Bakker, C., \& Gruis, V. (2017). Research bias in judgement bias studies - a systematic review of valuation judgement literature. Journal of Property Research, 34(4), 285-304. https://doi.org/10.1080/09599916.2017.1379552

Krause, A. L., \& Bitter, C. (2012). Spatial econometrics, land values and sustainability: trends in real estate valuation research. Cities, 29, S19-S25. https://doi.org/10.1016/j.cities.2012.06.006

Lacour-Little, M., \& Malpezzi, S. (2003). Appraisal quality and residential mortgage default: evidence from Alaska. Journal of Real Estate Finance and Economics, 27(2), 211-233. https://doi.org/10.1023/A:1024728420837

Levy, D., \& Schuck, E. (1999). The influence of clients on valuations. Journal of Property Investment \& Finance, 17(4), 380400. https://doi.org/10.1108/14635789910271773

Levy, D., \& Schuck, E. (2005). The influence of clients on valuations: the clients' perspective. Journal of Property Investment \& Finance, 23(2), 182-201. https://doi.org/10.1108/14635780510584364
Ministerial Order ECO/805/2003, BOE 27 March 2003.

Moran, P. (1950). A test for the serial independence of residuals. Biometrika, 37(1/2), 178-181. https://doi.org/10.2307/2332162

Montalvo, J. G., \& Raya, J. M. (2017). Constraints on LTV as a macroprudential tool: a precautionary tale. Department of Economics and Business, Universitat Pompeu Fabra. Forthcoming in Oxford Economic papers.

Royal Decree 775/1997, BOE 30 May 1997.

Salon, D., Wu, J., \& Shewmake, S. (2014). Impact of bus rapid transit and metro rail on property values in Guangzhou, China. Transportation Research Record. Journal of the Transportation Research Board, (2452), 36-45. https://doi.org/10.3141/2452-05

Tidwell, O. A., \& Gallimore, P. (2014). The influence of a decision support tool on real estate valuations. Journal of Property Research, 31(1), 45-63. https://doi.org/10.1080/09599916.2013.819519

Zhang, R., Du, Q., Geng, J., Liu, B., \& Huang, Y. (2015). An improved spatial error model for the mass appraisal of commercial real estate based on spatial analysis: Shenzhen as a case study. Habitat International, 46, 196-205. https://doi.org/10.1016/j.habitatint.2014.12.001 